\title{
Hormetic Effects of Mixtures of Carbendazim and Iprodione on the Virulence of Botrytis cinerea
}

\author{
Menglong Cong, Shun He, Jun Zhang, Chaoxi Luo, and Fuxing Zhu, ${ }^{\dagger}$ College of Plant Science and Technology, Huazhong Agricultural \\ University, Wuhan, 430070, China
}

\begin{abstract}
Hormetic effects of fungicides on mycelial growth and virulence of plant pathogenic fungi have been reported, but the effects of fungicide mixtures on virulence hormesis of plant pathogens remain to be investigated. In this study, hormetic effects of mixtures of carbendazim and iprodione on the virulence of two carbendazim-resistant isolates of Botrytis cinerea were determined. Spraying carbendazim alone at 3 to $800 \mu \mathrm{g} / \mathrm{ml}$ exhibited hormetic effects on virulence to cucumber leaves, and carbendazim at $10 \mu \mathrm{g} / \mathrm{ml}$ had the maximum stimulation of $16.7 \%$ for isolate HBtom451. Spraying iprodione alone at 0.0001 to $0.0625 \mu \mathrm{g} / \mathrm{ml}$ exhibited hormetic effects on virulence, and iprodione at $0.025 \mu \mathrm{g} / \mathrm{ml}$ had the maximum stimulation of $18.7 \%$ for isolate HBtom 451 . However, spraying simultaneously carbendazim at $800 \mu \mathrm{g} / \mathrm{ml}$ and iprodione at $0.0625 \mu \mathrm{g} / \mathrm{ml}$ showed inhibitory effects on virulence to cucumber leaves. The mixture of carbendazim at $3 \mu \mathrm{g} / \mathrm{ml}$ and iprodione at $0.0001 \mu \mathrm{g} / \mathrm{ml}$ had much higher virulence stimulations than either fungicide at the same concentration alone. The maximum stimulation for the mixtures occurred

at 10 and $0.0005 \mu \mathrm{g} / \mathrm{ml}$ for carbendazim and iprodione, respectively, and these concentrations were much lower than the concentration of their respective fungicide alone eliciting the maximum stimulations. The maximum stimulation amplitude for the mixture was slightly higher than that of each fungicide alone. These results demonstrated that carbendazim and iprodione mainly had dose-additive rather than amplitude-additive interactions when sprayed simultaneously with regard to virulence stimulations. Studies on virulence stimulations for mycelia treated with fungicide in potato dextrose agar showed that the maximum stimulation for the mixtures occurred at concentrations much lower than the concentration of carbendazim alone, indicating a dose-additive interaction when compared with carbendazim hormesis. Studies on potential physiological mechanisms of hormesis showed that increased tolerance to $\mathrm{H}_{2} \mathrm{O}_{2}$ may be one of the mechanisms for virulence hormesis for the mixtures of iprodione and carbendazim. These studies will advance our understanding of hormesis of fungicide mixtures.
\end{abstract}

The necrotrophic plant pathogenic fungus Botrytis cinerea Pers. Fr. can infect more than 1,400 plant species in 586 genera across the world. The extremely broad host spectrum mainly comprises dicotyledonous plants, many of which are economically important fruit and vegetable crops (Elad et al. 2015; Van Kan et al. 2017). Gray mold caused by $B$. cinerea usually leads to serious economic losses to the production of many fruit and vegetable crops such as grapes and tomatoes. So far, no crop cultivars with complete resistance to this pathogen have been successfully developed. B. cinerea can produce huge amounts of conidia in a favorable environment and form highly resistant sclerotia as a survival structure in an adverse environment. $B$. cinerea has evolved exquisite infection tactics to efficiently attack a fairly wide range of plants, making it one of the most successful plant pathogenic fungi on earth (Amselem et al. 2011; Williamson et al. 2007). Therefore, it has been traditionally difficult to control this intractable pathogen. Among the integrated management tactics, fungicides remain a primary approach to controlling $\mathrm{B}$. cinerea (Mbengue et al. 2016; Nakajima and Akutsu 2014).

Among the various fungicides registered in China for control of gray mold, the benzimidazole fungicide carbendazim is one of the most widely used compounds, although mainly as mixtures with other fungicides of different modes of action or different chemical groups such as pyrimethanil, iprodione, and diethofencarb (http:// www.chinapesticide.org.cn/hysj/index.jhtml). Carbendazim is a typical single site of action fungicide, and point mutations of E198A/G/ $\mathrm{K} / \mathrm{V}$ and $\mathrm{F} 200 \mathrm{Y}$ in the target $\beta$-tubulin gene usually lead to high and

${ }^{\dagger}$ Corresponding author: Fuxing Zhu; E-mail: zhufuxing@mail.hzau.edu.cn

M. Cong and S. He contributed equally to this article.

Funding: This study was supported by the National Natural Science Foundation of China (31371964)

Accepted for publication 4 July 2018.

(C) 2019 The American Phytopathological Society moderate levels of resistance in plant pathogenic fungi (Banno et al. 2008). The Fungicide Resistance Action Committee (FRAC 2018) lists the benzimidazole fungicides as having a high risk for resistance development. The resistance of $B$. cinerea to benzimidazole fungicides is prevalent, and carbendazim resistance has been reported across the world (Konstantinou et al. 2015; Rupp et al. 2016; Saito et al. 2016). In China, although carbendazim has been primarily used as mixtures with other fungicides for control of gray mold in the last several decades, different levels of carbendazim resistance have also been reported (Liu et al. 2014; Zhang et al. 2006; Zhou and Ye 1987).

The development and prevalence of fungicide resistance have serious implications for control of plant pathogens. High levels of resistance will result in control failures for fungicide in the field. More importantly and unexpectedly, fungicides applied in the field may stimulate rather than inhibit plant pathogens in some situations, especially for resistant strains. In fact, some farmers have witnessed more serious disease outbreaks after application of fungicides than the nontreated control. In the fields, pathogens will be exposed to sublethal doses of the applied fungicides because of the drift of sprayed droplets, degradation of fungicides, and different penetrations through crop canopies. Concentrations recommended on the packaging labels are effective to the sensitive strains of the target pathogen and will become sublethal or relatively low dosages for the resistant strains (Garzón and Flores 2013). Low dosages of fungicides may stimulate mycelial growth and virulence of plant pathogenic fungi. Stimulatory effects of carbendazim on the virulence of resistant isolates of $B$. cinerea have been reported recently (Cong et al. 2018). Our previous studies also reported stimulatory effects of low doses of dimethachlone (Zhou et al. 2014) on mycelial growth and virulence, and trifloxystrobin (Di et al. 2016a), carbendazim (Di et al. 2015, 2016b), and flusilazole (Lu et al. 2018a, b) on the virulence of Sclerotinia sclerotiorum. In addition, stimulatory effects of low doses of fungicides on a variety of fungi have also been documented, such as stimulatory effects of sublethal doses of thiabendazole on spore germination of Penicillium expansum (Baraldi et al. 2003), propamocarb on mycelial growth of Lyophyllum palustre (Landry et al. 2011), prothioconazole on the production of the mycotoxin deoxynivalenol in Fusarium graminearum (Audenaert et al. 
2010), propamocarb and cyazofamid on mycelial growth of Pythium aphanidermatum (Flores and Garzón 2013), mefenoxam on mycelial growth and virulence of $P$. aphanidermatum (Garzón et al. 2011; Moorman and Kim 2004), and metalaxyl on mycelial growth of Phytophthora infestans (Zhang et al. 1997). These stimulatory effects of different chemical groups of fungicides on various plant pathogenic fungi and oomycetes reflect a general biological phenomenon widely known as hormesis. In the disciplines of toxicology and pharmacology, hormesis is defined as a kind of dose-response relationship characterized by a high-dose inhibition and a low-dose stimulation (Calabrese 2015a). It is a nonmonotonic, biphasic dose response and has distinctive dose-response features. The strong majority of hormetic responses display maximum stimulation less than twice that of the control group and usually 30 to $60 \%$ greater than the control group, and the stimulatory dose widths are usually within approximately 10 - to 20 -fold of the estimated toxicological threshold (Calabrese and Blain 2011). Hormetic responses have been reported across a broad range of biological models such as plants, microbes, invertebrates, and vertebrates, encompassing a large number and range of endpoints, and across a great diversity of agents including chemicals, ionizing radiations, and physical stresses. Hormetic dose responses may provide a quantitative estimate of biological plasticity that is broadly generalizable (Calabrese 2013, 2015a, b, 2016a, b).

Although chemical hormesis is generalizable, and a large number of hormetic responses of plant pathogenic fungi to low doses of fungicides have been reported, hormesis concerning fungicide mixtures is rare and remains to be studied. As stated above, carbendazim is mainly employed in China as mixtures with other fungicides to control $B$. cinerea. Therefore, it is of practical significance to investigate stimulatory effects of mixtures of carbendazim with other fungicides on $B$. cinerea. The stimulatory effects of sublethal doses of carbendazim alone on the virulence of $B$. cinerea have been reported (Cong et al. 2018); it is time to study hormetic effects of carbendazim mixtures. Exopolysaccharide (EPS) can provide energy for fungal pathogens to invade host plants and is an important virulence factor (Dharmapuri et al. 2001). Increased tolerance to hydrogen peroxide $\left(\mathrm{H}_{2} \mathrm{O}_{2}\right)$ may facilitate successful infections of fungal pathogens, because most host plants will release reactive oxygen species to combat against early infects of pathogens (Williams et al. 2011). Investigating effects of carbendazim and iprodione on EPS content and tolerance of $B$. cinerea to $\mathrm{H}_{2} \mathrm{O}_{2}$ may shed light on hormetic mechanisms of fungicides. The objectives of the present study were to (i) assess hormetic effects of low doses of mixtures of carbendazim with iprodione on the virulence of $B$. cinerea, (ii) determine potential interactions between carbendazim and iprodione with respect to virulence hormesis, and (iii) explore underlying mechanisms for hormetic effects of carbendazim and iprodione on the virulence of B. cinerea.

\section{Materials and Methods}

Isolates of $\boldsymbol{B}$. cinerea. The two isolates of $B$. cinerea employed in the present study were kindly provided by G. Q. Li of Huazhong Agricultural University. The two isolates HBtom451 and HBstr491 were collected from diseased tomato and strawberry, respectively, both from commercial fields of Hubei Province. Mycelial colonies of both isolates were maintained on potato dextrose agar (PDA) slants in round-bottom polystyrene tubes at $4^{\circ} \mathrm{C}$. Bioassay experiments based on mycelial growth inhibitions on PDA amended with fungicides indicated that the concentrations that reduce mycelial growth by $50 \%$ ( $\mathrm{EC}_{50}$ values) of carbendazim to the two isolates were higher than $1,000 \mu \mathrm{g} / \mathrm{ml}$.

Fungicides. Technical-grade carbendazim ( $98.1 \%$ active ingredient [a.i.], Tian Jin Jin Bei Chemical Co.) was dissolved in 0.1 M hydrochloric acid $(\mathrm{HCl})$ to produce a $20,000 \mu \mathrm{g} / \mathrm{ml}$ stock solution. Technical-grade iprodione $(95.3 \%$ a.i., Hubei Kang Bao Tai FineChemical Co.) was dissolved in acetone to produce a $10,000 \mu \mathrm{g} / \mathrm{ml}$ stock solution. These stock solutions were stored at $4{ }^{\circ} \mathrm{C}$ for no more than 2 weeks before being serially diluted for subsequent experiments.

Stimulatory effects of spraying sublethal doses of carbendazim, iprodione, and their mixtures on the virulence of $B$. cinerea to detached cucumber leaves. The method for this experiment was according to Cong et al. (2018) and Di et al. (2016a). The carbendazim stock solution was serially diluted with $0.1 \mathrm{M} \mathrm{HCl}$ solution to concentrations of $8,000,2,000,500,100$, and $30 \mu \mathrm{g} / \mathrm{ml}$. The iprodione stock solution was serially diluted with acetone to concentrations of $0.625,0.125,0.025,0.005$, and $0.001 \mu \mathrm{g} / \mathrm{ml}$. These carbendazim and iprodione dilutions were further diluted 10-fold with water containing $0.1 \%$ Triton X-100. Leaves of approximately 9 to $12 \mathrm{~cm}$ in diameter were detached from 5-week-old cucumber plants growing in the greenhouse at $25^{\circ} \mathrm{C}$. The detached leaves were rinsed with sterile water, air dried for $1 \mathrm{~h}$, transferred to $15-\mathrm{cm}$ diameter Petri dishes lined with wetted filter paper to maintain high humidity, and then sprayed with carbendazim and iprodione dilutions with a handheld sprayer $(800 \mathrm{ml}$ in volume, Xinmeir Co.). Leaves in Petri dishes were randomly divided into three groups. One group of leaves was sprayed with carbendazim dilutions alone, and another group of leaves was sprayed with iprodione dilutions alone. The third group of leaves was sprayed with the same volume of carbendazim and iprodione dilutions at the following concentrations: 3 (carbendazim) +0.0001 (iprodione), $10+0.0005,50+$ $0.0025,200+0.0125$, and $800+0.0625 \mu \mathrm{g} / \mathrm{ml}$. There were three replicate leaves for each treatment. Cucumber leaves sprayed with $0.01 \mathrm{M} \mathrm{HCl}$ in $0.1 \%$ Triton $\mathrm{X}-100$ were used as the nontreated control for carbendazim, treatments with $10 \%$ acetone in $0.1 \%$ Triton $\mathrm{X}$ 100 in water were used as the nontreated control for iprodione, and treatments with the same volume of $0.01 \mathrm{M} \mathrm{HCl}$ and $10 \%$ acetone in $0.1 \%$ Triton $\mathrm{X}-100$ were used as the control for the mixtures. After being air dried for $1 \mathrm{~h}$, leaves were inoculated with inverted 2-dayold mycelial plugs ( $5 \mathrm{~mm}$ in diameter) cut from fresh margins of actively growing mycelial colonies on the adaxial surface of leaves, one plug per leaf. The inoculated leaves were incubated at $25^{\circ} \mathrm{C}$ for $72 \mathrm{~h}$ in a growth chamber with relative humidity maintained at approximately $90 \%$. The diameter of each lesion was measured twice at right angles. The experiment was conducted in triplicate and performed independently three times.

Stimulatory effects of growing on fungicide-amended PDA on the virulence of $B$. cinerea to detached leaves of cucumber plants. The method for this experiment was according to that of Cong et al. (2018). The stock solutions of carbendazim and iprodione were serially diluted with $0.1 \mathrm{M} \mathrm{HCl}$ and acetone, respectively. The diluted carbendazim and iprodione solutions were added to autoclaved PDA at about $55^{\circ} \mathrm{C}$, at a volume ratio 1:99. The final concentrations of carbendazim in PDA were $0.02,0.08,0.4,2,8,40,200$, and $800 \mu \mathrm{g} / \mathrm{ml}$, and the final concentrations for iprodione were $0.00005,0.0002,0.001,0.005,0.02,0.1,0.5$, and $2 \mu \mathrm{g} / \mathrm{ml}$. For the mixture treatments, the same volume of carbendazim and iprodione dilutions were added into the autoclaved PDA, and the final concentrations in PDA were 0.02 (carbendazim) +0.00005 (iprodione), $0.08+0.0002,0.4+0.001,2+0.005,8+0.02,40+0.1$, $200+0.5$, and $800+2 \mu \mathrm{g} / \mathrm{ml}$. PDA plates amended with the same volume of acetone and $0.1 \mathrm{M} \mathrm{HCl}$ as each fungicide-alone treatment were used as nontreated controls for iprodione and carbendazim, respectively, and PDA plates amended with both acetone and $\mathrm{HCl}$ were used as the control for the mixture treatments. Mycelial cultures of the two isolates were grown on fungicide-amended PDA prepared as described above for $72 \mathrm{~h}$, and PDA plugs were cut with a 5-mm diameter cork borer from the actively growing margins of colonies. Leaves of about 9 to $12 \mathrm{~cm}$ in diameter were detached from 5week-old cucumber plants growing in the greenhouse at $25^{\circ} \mathrm{C}$. The detached leaves were rinsed, air dried, and transferred to Petri dishes as described above. Leaves were inoculated with mycelial plugs on the adaxial surface. The inoculated leaves were incubated at $25^{\circ} \mathrm{C}$ for $72 \mathrm{~h}$ in a growth chamber with relative humidity maintained at approximately $90 \%$. The diameter of each lesion was measured twice at right angles. The experiment was conducted in triplicate and performed independently three times.

Effects of carbendazim and iprodione on mycelial cell membrane permeability. Mycelial cell membrane permeability was measured according to the method of Lu et al. (2015). The two isolates of $B$. cinerea were cultured at $23^{\circ} \mathrm{C}$ for $72 \mathrm{~h}$ on 
cellophane-overlaid PDA containing carbendazim at 8 and 800 $\mu \mathrm{g} / \mathrm{ml}$, iprodione at 0.02 and $2 \mu \mathrm{g} / \mathrm{ml}$, the mixture of carbendazim at $8 \mu \mathrm{g} / \mathrm{ml}$ and iprodione at $0.02 \mu \mathrm{g} / \mathrm{ml}$, and the mixture of carbendazim at $800 \mu \mathrm{g} / \mathrm{ml}$ and iprodione at $2 \mu \mathrm{g} / \mathrm{ml}$. Mycelia grown on PDA amended with the same volume of acetone, $0.1 \mathrm{M} \mathrm{HCl}$, and both acetone and $\mathrm{HCl}$ as that of each fungicide were used as the nontreated controls for iprodione, carbendazim, and the mixture treatments, respectively. Mycelia were harvested by gentle scraping with a weighing spoon. Approximately $0.30 \mathrm{~g}$ of mycelia per sample was suspended in $40 \mathrm{ml}$ of double-distilled water in a 100-ml sterilized beaker, and the beaker was gently shaken for $3 \mathrm{~s}$ by hand. After $5,10,20,40,60,80,100,120,140,160$, and 180 min of suspension, the electrical conductivity of the double-distilled water was measured at room temperature with an electrical conductivity meter (DDS-12DW, Shuanxu Electronics Co., Shanghai, China). After the last measurement, the mycelial suspensions were boiled for $5 \mathrm{~min}$, and the final conductivity was measured. The relative conductivity was calculated by the following formula: relative conductivity $(\%)=$ conductivity/final conductivity $\times 100 \%$. The experiment was conducted in triplicate and performed independently three times.

Effects of carbendazim and iprodione on tolerance of $\mathrm{B}$. cinerea to hydrogen peroxide $\left(\mathrm{H}_{2} \mathrm{O}_{2}\right)$. The method was according to those of Di et al. (2015) and Cong et al. (2018). Fungicide-amended PDA was prepared as described above in the section "Stimulatory effects of growing on fungicide-amended PDA on the virulence of $B$. cinerea to detached leaves of cucumber plants". For isolate HBtom451, the concentrations of fungicides in PDA were as follows: carbendazim at $8 \mu \mathrm{g} / \mathrm{ml}+$ iprodione at $0.02 \mu \mathrm{g} / \mathrm{ml}$, and carbendazim at $800 \mu \mathrm{g} / \mathrm{ml}+$ iprodione at $2 \mu \mathrm{g} / \mathrm{ml}$. For isolate HBstr491, the concentrations of fungicides were as follows: carbendazim at $2 \mu \mathrm{g} / \mathrm{ml}+$ iprodione at $0.005 \mu \mathrm{g} / \mathrm{ml}$, and carbendazim at $200 \mu \mathrm{g} / \mathrm{ml}+$ iprodione at $0.5 \mu \mathrm{g} / \mathrm{ml}$. Mycelia of the two isolates were grown on fungicideamended PDA at $23^{\circ} \mathrm{C}$ for $72 \mathrm{~h}$. Mycelial plugs were cut from actively growing margins of cultural colonies and inoculated on PDA medium amended with $\mathrm{H}_{2} \mathrm{O}_{2}$ at 0,200 , and $400 \mu \mathrm{g} / \mathrm{ml}$. Mycelial plugs cut from culture colonies grown on PDA amended with the same volume of acetone, $0.1 \mathrm{M} \mathrm{HCl}$, and with both acetone and $\mathrm{HCl}$ were used as nontreated controls for iprodione, carbendazim, and the mixtures, respectively. The diameter of each mycelial colony was measured twice at right angles after being incubated at $23^{\circ} \mathrm{C}$ for $72 \mathrm{~h}$. The experiment was conducted in triplicate and performed independently three times.

Effects of carbendazim and iprodione on EPS content of B. cinerea. EPS content was determined by the phenol-sulfuric acid method according to the method of Duan et al. (2013). The cellophane-overlaid PDA was supplemented with carbendazim and iprodione. Fungicides in PDA for mixture treatment were as follows: carbendazim at $2 \mu \mathrm{g} / \mathrm{ml}+$ iprodione at $0.005 \mu \mathrm{g} / \mathrm{ml}$, and carbendazim at $200 \mu \mathrm{g} / \mathrm{ml}+$ iprodione at $0.5 \mu \mathrm{g} / \mathrm{ml}$. Mycelia were grown at $23^{\circ} \mathrm{C}$ for $72 \mathrm{~h}$ on cellophane-overlaid PDA amended with fungicides as described above and harvested by gently scraping with a weighing spoon. Approximately $0.30 \mathrm{~g}$ of mycelia was put into a 5-ml centrifuge tube containing $1 \mathrm{ml}$ of double-distilled water. The mycelia suspended in water were ground with an automatic sample grinder (JKFSTPRP24, Shanghai Jinxin Industrial Development Co.) and centrifuged at $10,000 \mathrm{rpm}$ for $10 \mathrm{~min}$, and all the supernatant was poured into a 5$\mathrm{ml}$ centrifuge tube containing $3 \mathrm{ml}$ of absolute ethanol. The samples were left for $5 \mathrm{~min}$ to let the polysaccharide precipitate. The liquid was discarded, the sediment was suspended in $10 \mathrm{ml}$ of doubledistilled water, and EPS was measured as described in the following paragraph for preparation of the standard curve. EPS content was extrapolated from absorbance results at $490 \mathrm{~nm}$ by comparison with the standard curve. The experiment was performed in triplicate and conducted independently twice.

For preparation of an EPS standard curve, 0, 0.1, 0.2, 0.3, 0.4, 0.5, $0.6,0.7,0.8,0.9$, and $1.0 \mathrm{ml}$ of glucose solution at $200 \mu \mathrm{g} / \mathrm{ml}$ was poured separately into 11 tubes, and double-distilled water was added into each tube to the final volume of $1 \mathrm{ml}$. Then $1 \mathrm{ml}$ of $5 \%$ phenol in water was added to each test tube. After the tubes were vortexed, $5 \mathrm{ml}$ of concentrated $\mathrm{H}_{2} \mathrm{SO}_{4}$ was then added slowly along the tube wall into each test tube, and the liquid was mixed thoroughly again. The test tubes were incubated at $90^{\circ} \mathrm{C}$ for $15 \mathrm{~min}$. The absorbance of the solutions at $490 \mathrm{~nm}$ was measured by a spectrophotometer. A standard curve was generated by plotting absorbance against glucose concentrations.

Data processing and analysis. Percent stimulations of virulence were calculated by the following formula: percent stimulation $(\%)=[$ (lesion diameter of the treated - lesion diameter of the control)/lesion diameter of the control] $\times 100 \%$. Curve modeling was performed according to the method of Deng et al. (2001) with the second-order polynomial (quadratic) procedure in Microsoft Excel software (version 2010, Microsoft Corporation, Redmond, WA), and figures were constructed also with Microsoft Excel. Following analysis of variance, the multiple-comparison procedure Dunnett in SPSS (Statistical Product and Service Solutions, version 21.0, SPSS, Chicago, IL) with the nontreated control as the control group was used to test significant differences in EPS contents and in colony diameters on PDA amended with $\mathrm{H}_{2} \mathrm{O}_{2}$.

\section{Results}

Stimulatory effects of spraying sublethal doses of carbendazim, iprodione, and their mixtures on the virulence of $B$. cinerea to detached cucumber leaves. For the two carbendazim-resistant isolates tested, spraying carbendazim alone at 3 to $800 \mu \mathrm{g} / \mathrm{ml}$ had hormetic effects on virulence to cucumber leaves (Fig. 1). Carbendazim at $10 \mu \mathrm{g} / \mathrm{ml}$ had the maximum stimulation of $16.7 \% \pm 3.9$ (SEM) for isolate HBtom451. Spraying iprodione alone at 0.0001 to $0.0625 \mu \mathrm{g} / \mathrm{ml}$ also exhibited hormetic effects on virulence, and iprodione at $0.025 \mu \mathrm{g} / \mathrm{ml}$ had the maximum stimulation of $18.7 \% \pm 4.5$ (SEM) for isolate HBtom451. When carbendazim and iprodione were sprayed simultaneously at the concentrations indicated in Figure 1, parabolic stimulation curves for virulence were generated for the two isolates, and the stimulation curves shifted to the left compared with those of carbendazim and iprodione alone. Spraying
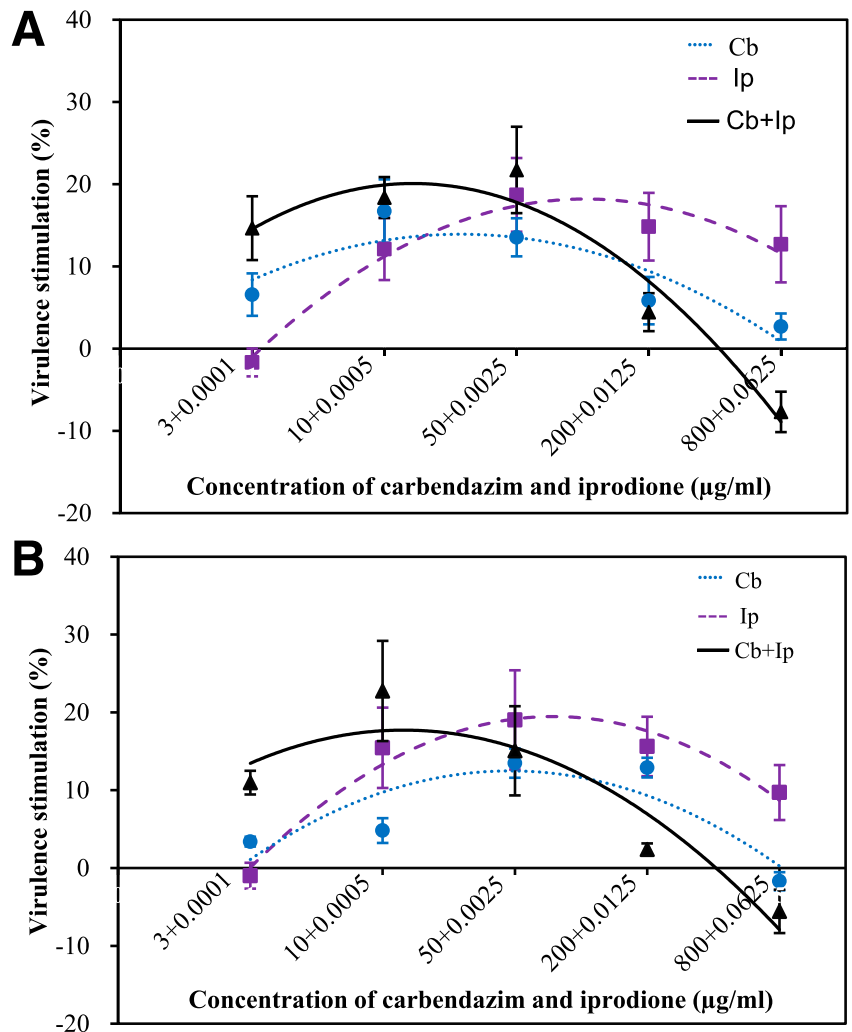

Fig. 1. Stimulatory effects of spraying carbendazim (Cb), iprodione (Ip), and their mixtures on the virulence of Botrytis cinerea isolates HBtom451 (A) and HBstr491 (B) on detached cucumber leaves. Error bars denote the standard error of the mean of three repeated experiments. Numbers before and after the plus sign "+ on the $x$ axis denote the concentrations of carbendazim and iprodione, respectively. 
simultaneously carbendazim at $800 \mu \mathrm{g} / \mathrm{ml}$ and iprodione at $0.0625 \mu \mathrm{g} /$ $\mathrm{ml}$ showed inhibitory effects on virulence to cucumber leaves. The mixture of carbendazim at $3 \mu \mathrm{g} / \mathrm{ml}$ and iprodione at $0.0001 \mu \mathrm{g} / \mathrm{ml}$ had much higher virulence stimulations than either fungicide alone. The maximum virulence stimulation for the mixtures occurred with carbendazim at $10 \mu \mathrm{g} / \mathrm{ml}$ and iprodione at $0.0005 \mu \mathrm{g} / \mathrm{ml}$. The maximum stimulation amplitude for the mixture was slightly higher than that of each fungicide alone. These results demonstrated that the mixtures of carbendazim and iprodione mainly had doseadditive rather than amplitude-additive interactions in regard to virulence stimulations.

Stimulatory effects of growing on fungicide-amended PDA on the virulence of $\boldsymbol{B}$. cinerea. For isolate HBtom451, carbendazim at $40 \mu \mathrm{g} / \mathrm{ml}$ in PDA showed the highest stimulatory effects on the virulence of $B$. cinerea (Fig. 2). For isolate HBstr491, carbendazim at $200 \mu \mathrm{g} / \mathrm{ml}$ had the highest stimulatory effects of $9.1 \% \pm 2.0$ (SEM). Carbendazim in PDA at $200 \mu \mathrm{g} / \mathrm{ml}$ inhibited mycelial growth by $18.5 \%$ for isolate HBstr491. Iprodione in PDA at 0.5 and $2 \mu \mathrm{g} / \mathrm{ml}$ inhibited mycelial growth of isolate HBstr491 by 56.0 and $89.9 \%$, respectively. That was why mycelia grown on PDA supplemented with iprodione at $2 \mu \mathrm{g} / \mathrm{ml}$ could not be used for the determination of virulence. The relatively high inhibitory effects of iprodione at 0.5 and $2 \mu \mathrm{g} / \mathrm{ml}$ on mycelial growth of isolate HBtom 451 also caused inhibitions on the virulence to leaves.

Effects of carbendazim and iprodione on mycelial cell membrane permeability. Carbendazim and iprodione, either alone or in mixtures at low concentrations ( 2 and $8 \mu \mathrm{g} / \mathrm{ml}$ for carbendazim, and 0.005 and $0.02 \mu \mathrm{g} / \mathrm{ml}$ for iprodione) did not show any inhibitory effects on mycelial growth on PDA and on cell membrane permeability in comparison with nontreated controls (Fig. 3). Carbendazim at relatively high concentrations of 200 and $800 \mu \mathrm{g} / \mathrm{ml}$ did not have significant effects on mycelial growth or on cell membrane
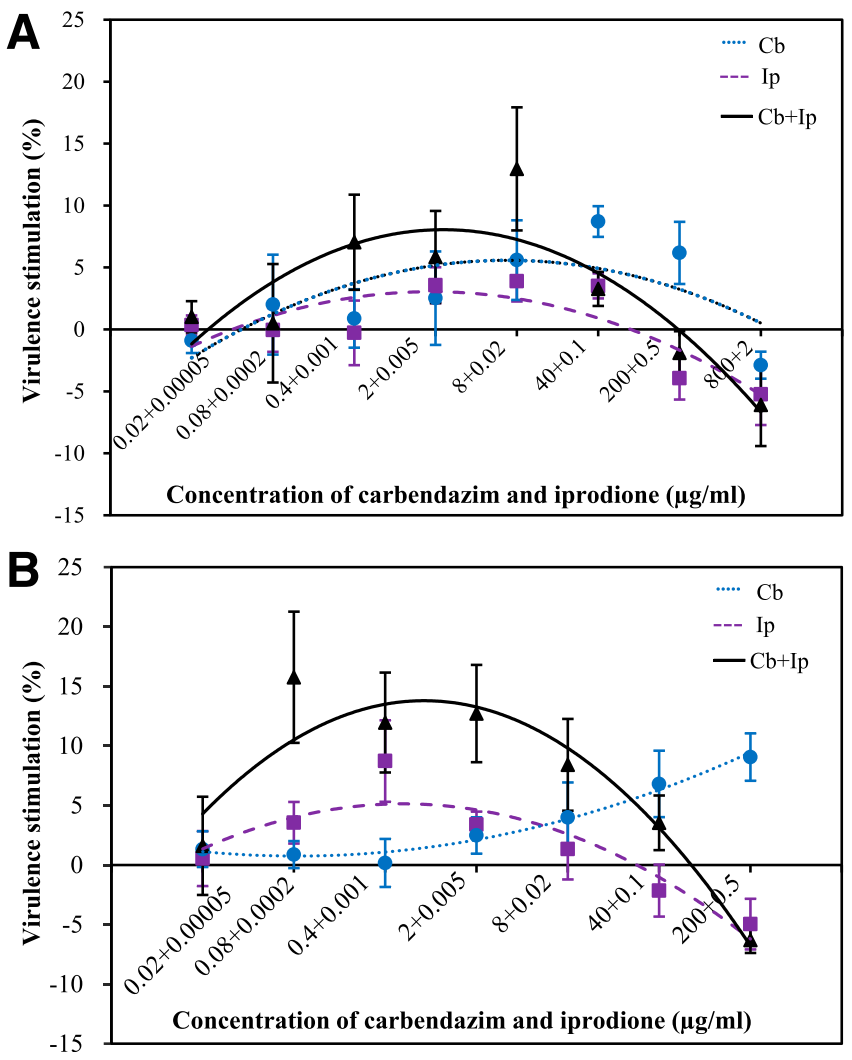

Fig. 2. Stimulatory effects of growing on potato dextrose agar (PDA) amended with carbendazim $(\mathrm{Cb})$ and iprodione (Ip) on the virulence of Botrytis cinerea isolates HBtom451 (A) and HBstr491 (B) on detached cucumber leaves. Error bars denote the standard error of the mean of three repeated experiments. Numbers before and after the plus sign " + " on the $x$ axis denote the concentrations of carbendazim and iprodione, respectively, in PDA medium. permeability. However, iprodione at relatively high concentrations of 0.5 and $2 \mu \mathrm{g} / \mathrm{ml}$ inhibited mycelial growth on PDA and increased cell membrane permeability. The mixture of carbendazim at $800 \mu \mathrm{g} /$ $\mathrm{ml}$ and iprodione at $2 \mu \mathrm{g} / \mathrm{ml}$ increased cell membrane permeability of isolate HBtom 451 to a similar extent as iprodione alone. The mixture of carbendazim at $200 \mu \mathrm{g} / \mathrm{ml}$ and iprodione at $0.5 \mu \mathrm{g} / \mathrm{ml}$ significantly ( $P<0.001$ according to paired $t$ test) increased cell membrane permeability of isolate HBstr491 compared with iprodione alone.

Effects of carbendazim and iprodione on tolerance of $\mathrm{B}$. cinerea to $\mathrm{H}_{2} \mathbf{O}_{2}$. Neither carbendazim at $2,8,200$, and $800 \mu \mathrm{g} / \mathrm{ml}$ nor iprodione at 0.005 and $0.02 \mu \mathrm{g} / \mathrm{ml}$ in PDA had significant effects on tolerance of $S$. sclerotiorum mycelia to $\mathrm{H}_{2} \mathrm{O}_{2}$ (Fig. 4). However, mycelia of isolate HBtom451 grown on PDA amended with iprodione at $2 \mu \mathrm{g} / \mathrm{ml}$ and with the mixture of carbendazim at $800 \mu \mathrm{g} /$ $\mathrm{ml}$ and iprodione at $2 \mu \mathrm{g} / \mathrm{ml}$ showed slightly but statistically significantly $(P<0.05)$ increased tolerance to $\mathrm{H}_{2} \mathrm{O}_{2}$ at $400 \mu \mathrm{g} / \mathrm{ml}$ in comparison with the nontreated control. Similarly, mycelia of isolate HBstr491 grown on PDA amended with iprodione at $0.5 \mu \mathrm{g} / \mathrm{ml}$ and with the mixture of carbendazim at $200 \mu \mathrm{g} / \mathrm{ml}$ and iprodione at $0.5 \mu \mathrm{g} / \mathrm{ml}$ also showed slightly but statistically significantly $(P<0.05)$ increased tolerance to $\mathrm{H}_{2} \mathrm{O}_{2}$.

Effects of carbendazim and iprodione on EPS content. The effects of carbendazim and iprodione on EPS content were similar in amplitude to those on mycelia growth. Iprodione at $0.5 \mu \mathrm{g} / \mathrm{ml}$ and the mixture of carbendazim at $200 \mu \mathrm{g} / \mathrm{ml}$ and iprodione at $0.5 \mu \mathrm{g} / \mathrm{ml}$ have significant inhibitory effects on EPS content (Fig. 5). Carbendazim and iprodione showed additive interactions with respect to percent inhibition of EPS content.

\section{Discussion}

The present study investigated hormetic effects of mixtures of carbendazim and iprodione on the virulence of $B$. cinerea. Spraying sublethal doses of carbendazim, iprodione, and their mixtures had significant stimulatory effects on the virulence of $B$. cinerea to cucumber leaves, and the stimulation profiles were typical biphasic, parabolic curves and conformed to the concept of hormesis. Compared with stimulatory effects of spraying carbendazim and iprodione alone, the stimulatory profile for the mixtures of carbendazim and iprodione shifted to the left on the $x$ axis representing dosages. At the highest concentration of $800 \mu \mathrm{g} / \mathrm{ml}$ for carbendazim alone, virulence was comparable to the nontreated control, or near the nonobservable adverse-effect level in terms of hormesis (Calabrese 2015a). At the highest concentration of $0.0625 \mu \mathrm{g} / \mathrm{ml}$ for iprodione alone, the stimulatory effect on virulence was obvious. However, when spraying carbendazim at $800 \mu \mathrm{g} / \mathrm{ml}$ and iprodione at $0.0625 \mu \mathrm{g} / \mathrm{ml}$ simultaneously, significantly inhibitory effects on virulence were detected. These results indicate definitely the dose-additive interactions for carbendazim and iprodione. Studies on mycelia grown on PDA amended with fungicides also showed dose-additive interactions for carbendazim and iprodione. For isolate HBstr491, carbendazim in PDA at $200 \mu \mathrm{g} / \mathrm{ml}$ showed significant stimulation on virulence, whereas iprodione at $0.5 \mu \mathrm{g} / \mathrm{ml}$ showed significant inhibition on virulence. The mixture of carbendazim at 200 $\mu \mathrm{g} / \mathrm{ml}$ and iprodione at $0.5 \mu \mathrm{g} / \mathrm{ml}$ showed similar virulence inhibition as iprodione alone, indicating dose-additive rather than effectadditive interactions.

Maximum stimulation amplitude of spraying carbendazim and iprodione simultaneously was only slightly higher than those of carbendazim and close to those of iprodione. Mycelia grown on PDA amended with mixtures of carbendazim and iprodione showed slightly higher virulence on rapeseed leaves than those mycelia grown on PDA amended with each fungicide alone. On the whole, maximum stimulation of the mixture of carbendazim and iprodione did not increase significantly compared with those of carbendazim and iprodione alone. However, the doses for the mixture of carbendazim and iprodione eliciting maximum stimulations shifted to the left on the $x$ axis denoting fungicide dosage. At relatively lower doses, the stimulation amplitude for the mixture of carbendazim and iprodione was much higher than those of carbendazim and iprodione alone. For example, spraying carbendazim at $3 \mu \mathrm{g} / \mathrm{ml}$ showed 
only a slight stimulation of $6.58 \%$ on the virulence of isolate HBtom 451 , and iprodione at $0.0001 \mu \mathrm{g} / \mathrm{ml}$ had a stimulation of $-1.68 \%$ on virulence compared with the nontreated control. But simultaneously spraying carbendazim at $3 \mu \mathrm{g} / \mathrm{ml}$ and iprodione at $0.0001 \mu \mathrm{g} / \mathrm{ml}$ had a much higher virulence stimulation $(14.65 \%)$ than the sum of percent stimulations of the two fungicides for isolate HBtom451. In other words, at relatively low doses, synergistic interactions were found between carbendazim and iprodione with respect to stimulation amplitude. As fungicide dose increased, stimulation amplitude also increased, but as the stimulation amplitude approached to the limit of maximum stimulations, the interactions between carbendazim and iprodione became antagonistic with respect to virulence stimulations. A similar phenomenon has been reported with memory-enhancing drugs (Calabrese 2008; Calabrese and Mattson 2017).

This study investigated the effects of carbendazim, iprodione, and their mixtures on mycelial cell membrane permeability, tolerance to $\mathrm{H}_{2} \mathrm{O}_{2}$, and content of EPS. There are numerous factors in $B$. cinerea mediating penetration through host plant epidermis and destroying living tissues. Cell wall-degrading enzymes such as cutinase and cellulose may facilitate penetrations through plant epidermis, whereas toxins, oxalic acid, and reactive oxygen species (ROS) may contribute to the killing of the host cells. Oxidative burst, that is, rapidly releasing ROS such as $\mathrm{H}_{2} \mathrm{O}_{2}$ and superoxide radical, is an early and universal plant response following pathogen challenge (Nakajima and Akutsu 2014). Therefore, increased tolerance of pathogens to ROS facilitates their successful infections. $\mathrm{H}_{2} \mathrm{O}_{2}$ is one of the major ROS released by host plants as an early defense response to the initial pathogen challenge (Williams et al. 2011; Wojtaszek 1997). Our earlier studies showed that mycelia of $S$. sclerotiorum grown on dimethachlone-amended PDA are more virulent to host plants and at the same time more tolerant to $\mathrm{H}_{2} \mathrm{O}_{2}$ (Zhou et al. 2014). However, sublethal doses of carbendazim did not promote tolerance of $S$. sclerotiorum (Di et al. 2015) and B. cinerea (Cong et al. 2018) to $\mathrm{H}_{2} \mathrm{O}_{2}$. The present study corroborates our previous studies that carbendazim alone cannot increase tolerance of $B$. cinerea to $\mathrm{H}_{2} \mathrm{O}_{2}$, whereas iprodione, belonging to the same dicarboximide class of fungicides as dimethachlone, slightly but statistically significantly enhanced tolerance to $\mathrm{H}_{2} \mathrm{O}_{2}$. The mixture of carbendazim and iprodione showed similarly enhanced tolerance to $\mathrm{H}_{2} \mathrm{O}_{2}$ in magnitude to that of iprodione alone. This may partially explain the stimulatory effects on the virulence of $B$. cinerea by iprodione and its mixtures with carbendazim.

The present study showed that iprodione and its mixtures with carbendazim at relatively higher doses inhibited content of EPS, whereas carbendazim did not exhibit significant effects on EPS production. These results indicate that EPS content unlikely can account for virulence stimulations. Although cell membrane permeability has
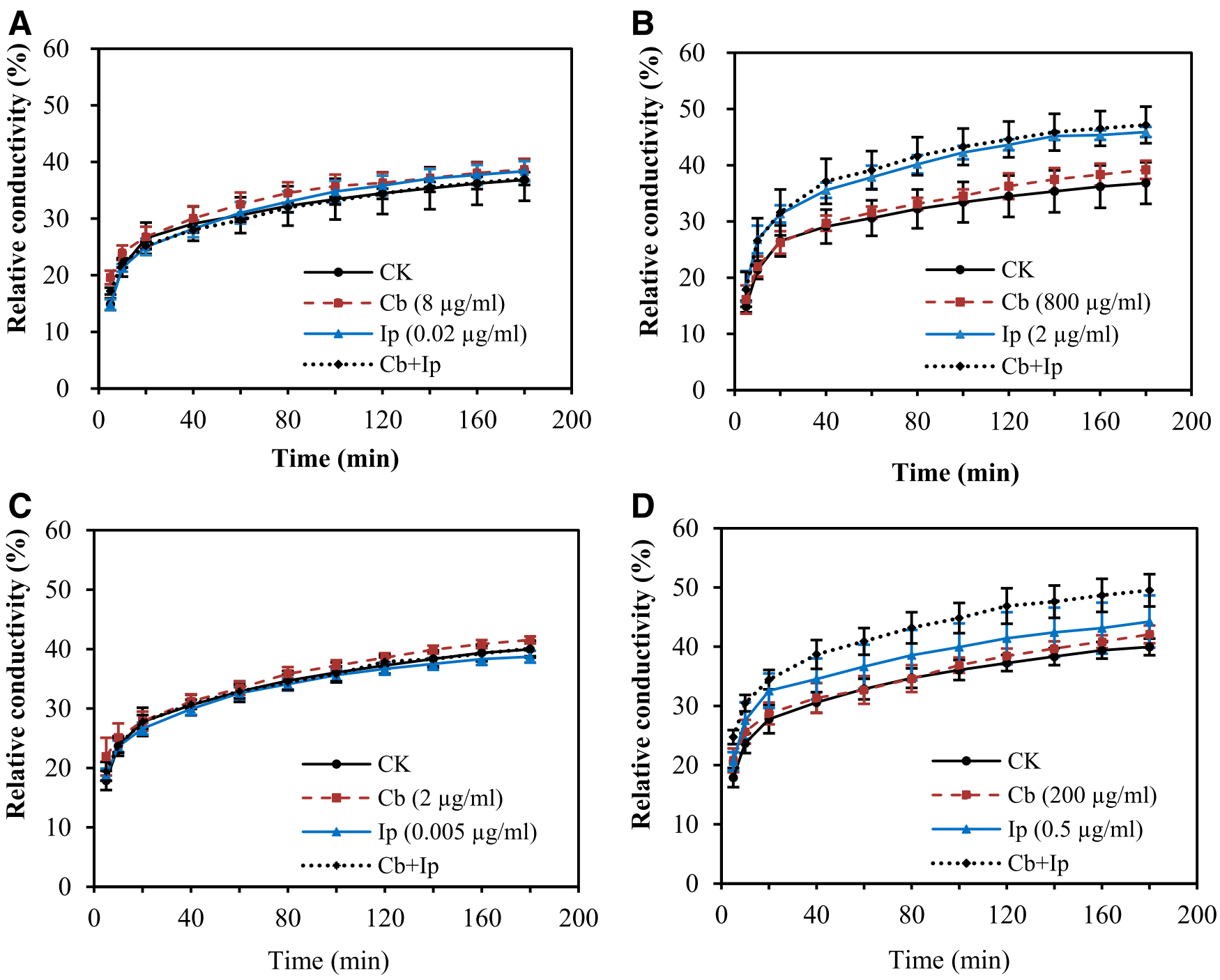

Fig. 3. Relative conductivity of water containing mycelia of Botrytis cinerea isolates HBtom451 (A and B) and HBstr491 (C and D) grown on cellophane-overlaid potato dextrose agar amended with carbendazim $(\mathrm{Cb})$, iprodione $(\mathrm{I} p)$, and their mixture. Error bars denote the standard error of the mean of three repeated experiments. $\mathrm{Cb}+\mathrm{lp}$ denotes the mixture of carbendazim and iprodione. CK denotes nontreated control. 
no direct correlation with the virulence of fungal pathogens, studies on effects of carbendazim and iprodione on cell membrane permeability demonstrated that there were additive and synergistic interactions between the two fungicides with respect to the amplitude of cell membrane permeability.

In determining hormetic effects of spraying carbendazim and iprodione on the virulence of $B$. cinerea, five concentrations for each fungicide were employed. For the treatment of growing on fungicideamended PDA, seven or eight concentrations for each fungicide were
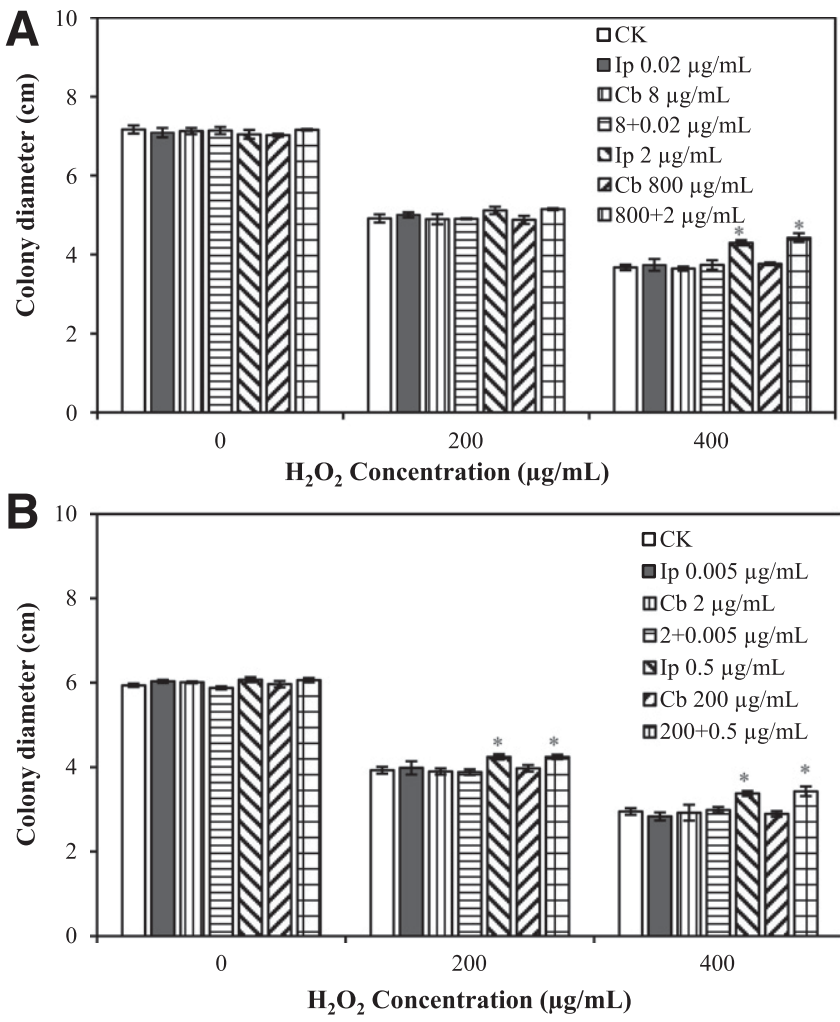

Fig. 4. Effects of carbendazim (Cb) and iprodione (Ip) on tolerance of Botrytis cinerea isolates HBtom451 (A) and HBstr491 (B) to $\mathrm{H}_{2} \mathrm{O}_{2}$. Error bar denotes the standard error of the mean of three repeated experiments. Asterisk denotes significant difference at an $\alpha$ level of 0.05 compared with the nontreated control. CK denotes nontreated control.

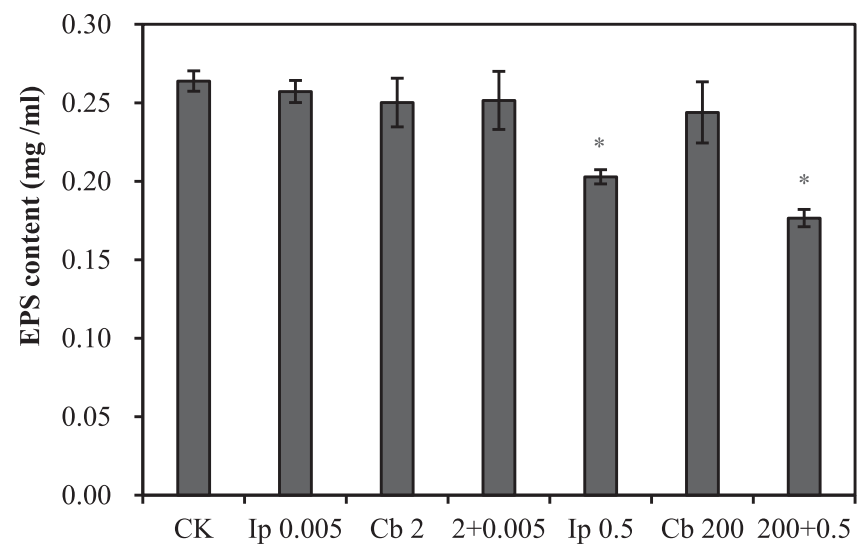

Carbendazim and iprodione concentrations $(\mu \mathrm{g} / \mathrm{ml})$

Fig. 5. Effects of carbendazim (Cb) and iprodione (Ip) on exopolysaccharide (EPS) content of Botrytis cinerea isolate HBstr491. Error bars denote the standard error of the mean of six replicates from two independently repeated experiments. There were no significant differences between the two repeated experiments; therefore, replicate data from each repeated experiment were pooled together. Asterisk denotes significant difference at an $\alpha$ level of 0.05 compared with the nontreated control. CK denotes nontreated control. used. These concentrations were chosen based on preliminary studies to generate parabolic stimulation curves by plotting percent stimulations against fungicide concentrations. Carbendazim and iprodione were not mixed at a fixed ratio but mixed according to their concentrations employed for each fungicide alone (i.e., the lowest concentration of carbendazim was mixed with the lowest concentration of iprodione, and the highest concentration of carbendazim was mixed with the highest concentration of iprodione). Thus, carbendazim at the approximate concentration with the highest stimulation amplitude would be mixed with iprodione at the approximate concentration eliciting the highest stimulation. The reason for mixing carbendazim with iprodione in this way was that this might be the best way to determine the interactions between component fungicides. As stated above, dose-additive interactions were found between carbendazim and iprodione with respect to hormetic effects on the virulence of B. cinerea. Of course, mixing fungicides at concentrations with different stimulatory or inhibitory effects merits studies in the future.

\section{Literature Cited}

Amselem, J., Cuomo, C. A., van Kan, J. A. L., Viaud, M., Benito, E. P., Couloux, A., Coutinho, P. M., de Vries, R. P., Dyer, P. S., Fillinger, S., Fournier, E., Gout, L., Hahn, M., Kohn, L., Lapalu, N., Plummer, K. M., Pradier, J. M., Quévillon, E., Sharon, A., Simon, A., ten Have, A., Tudzynski, B., Tudzynski, P., Wincker, P., Andrew, M., Anthouard, V., Beever, R. E., Beffa, R., Benoit, I., Bouzid, O., Brault, B., Chen, Z., Choquer, M., Collémare, J., Cotton, P., Danchin, E. G., Silva, D. C., Gautier, A., Giraud, C., Giraud, T., Gonzalez, C., Grossetete, S., Güldener, U., Henrissat, B., Howlett, B. J., Kodira, C., Kretschmer, M. Lappartient, A., Leroch, M., Levis, C., Mauceli, E., Neuvéglise, C., Oeser, B., Pearson, M., Poulain, J., Poussereau, N., Quesneville, H., Rascle, C. Schumacher, J., Ségurens, B., Sexton, A., Silva, E., Sirven, C., Soanes, D. M., Talbot, N. J., Templeton, M., Yandava, C., Yarden, O., Zeng, Q., Rollins, J. A., Lebrun, M. H., and Dickman, M. 2011. Genomic analysis of the necrotrophic fungal pathogens Sclerotinia sclerotiorum and Botrytis cinerea. PLoS Genet. 7:e1002230.

Audenaert, K., Callewaert, E., Höfte, M., Saeger, S. D., and Haesaert, G. 2010 Hydrogen peroxide induced by the fungicide prothioconazole triggers deoxynivalenol (DON) production by Fusarium graminearum. BMC Microbiol. 10:112.

Banno, S., Fukumori, F., Ichiishi, A., Okada, K., Uekusa, H., Kimura, M., and Fujimura, M. 2008. Genotyping of benzimidazole-resistant and dicarboximideresistant mutations in Botrytis cinerea using real-time polymerase chain reaction assays. Phytopathology 98:397-404.

Baraldi, E., Mari, M., Chierici, E., Pondrelli, M., Bertolini, P., and Pratella, G. C. 2003. Studies on thiabendazole resistance of Penicillium expansum of pears: Pathogenic fitness and genetic characterization. Plant Pathol. 52:362-370.

Calabrese, E. J. 2008. Hormesis and mixtures. Toxicol. Appl. Pharmacol. 229: 262-263.

Calabrese, E. J. 2013. Hormetic mechanisms. Crit. Rev. Toxicol. 43:580-606.

Calabrese, E. J. 2015a. Hormesis: Principles and applications. Homeopathy 104 69-82.

Calabrese, E. J. 2015b. Hormesis within a mechanistic context. Homeopathy 104: 90-96.

Calabrese, E. J. 2016a. Preconditioning is hormesis part I: Documentation, doseresponse features and mechanistic foundations. Pharmacol. Res. 110:242-264.

Calabrese, E. J. 2016b. Preconditioning is hormesis part II: How the conditioning dose mediates protection: Dose optimization within temporal and mechanistic frameworks. Pharmacol. Res. 110:265-275.

Calabrese, E. J., and Blain, R. B. 2011. The hormesis database: The occurrence of hormetic dose responses in the toxicological literature. Regul. Toxicol. Pharmacol. 61:73-81.

Calabrese, E. J., and Mattson, M. P. 2017. How does hormesis impact biology, toxicology, and medicine? NPJ Aging Mech. Dis. 3:13.

Cong, M. L., He, S., Ma, H. J., Li, G. Q., and Zhu, F. X. 2018. Hormetic effects of carbendazim on the virulence of Botrytis cinerea. Plant Dis. 102:886-891.

Deng, C., Graham, R., and Shukla, R. 2001. Detecting and estimating hormesis using a model-based approach. Hum. Ecol. Risk Assess. 7:849-866.

Dharmapuri, S., Yashitola, J., Vishnupriya, M. R., and Sonti, R. V. 2001. Novel genomic locus with atypical $\mathrm{G}+\mathrm{C}$ content that is required for extracellular polysaccharide production and virulence in Xanthomonas oryzae pv. oryzae. Mol. Plant-Microbe Interact. 14:1335-1339.

Di, Y. L., Cong, M. L., Zhang, R., and Zhu, F. X. 2016a. Hormetic effects of trifloxystrobin on aggressiveness of Sclerotinia sclerotiorum. Plant Dis. 100: 2113-2118.

Di, Y. L., Lu, X. M., Zhu, Z. Q., and Zhu, F. X. 2016b. Time-course of carbendazim stimulation on pathogenicity of Sclerotinia sclerotiorum indicates a direct stimulation mechanism. Plant Dis. 100:1454-1459.

Di, Y. L., Zhu, Z. Q., Lu, X. M., and Zhu, F. X. 2015. Pathogenicity stimulation of Sclerotinia sclerotiorum by subtoxic doses of carbendazim. Plant Dis. 99: 1342-1346. 
Duan, Y. B., Ge, C. Y., Liu, S. M., Chen, C. J., and Zhou, M. G. 2013. Effect of phenylpyrrole fungicide fludioxonil on morphological and physiological characteristics of Sclerotinia sclerotiorum. Pestic. Biochem. Physiol. 106:61-67.

Elad, Y., Pertot, I., Prado, A. M. C., and Stewart, A. 2015. Plant hosts of Botrytis spp. Pages 413-486 in: Botrytis-The Fungus, the Pathogen and Its Management in Agricultural Systems. S. Fillinger and Y. Elad, eds. Springer, Berlin, Germany.

Flores, F. J., and Garzón, C. D. 2013. Detection and assessment of chemical hormesis on the radial growth in vitro of oomycetes and fungal plant pathogens. Dose Response 11:361-373.

Fungicide Resistance Action Committee (FRAC). 2018. FRAC Code List 2018: Fungicide Sorted by Mode of Action. http://www.frac.info/docs/defaultsource/publications/frac-code-list/frac_code_list_2018-final.pdf?sfvrsn= 6144b9a_2

Garzón, C. D., and Flores, F. J. 2013. Hormesis: Biphasic dose-responses to fungicides in plant pathogens and their potential threat to agriculture. Pages 311-328 in: Fungicides: Showcases of Integrated Plant Disease Management from Around the World. M. Nita, ed. InTech, Rijeka, Croatia.

Garzón, C. D., Molineros, J. E., Yanez, J. M., Flores, F. J., Jimenez-Gasco, M. M., and Moorman, G. W. 2011. Sublethal doses of mefenoxam enhance Pythium damping-off of geranium. Plant Dis. 95:1233-1238.

Konstantinou, S., Veloukas, T., Leroch, M. Menexes, G., Hahn, M., and Karaoglanidis, G. 2015. Population structure, fungicide resistance profile, and $s d h B$ mutation frequency of Botrytis cinerea from strawberry and greenhouse-grown tomato in Greece. Plant Dis. 99:240-248.

Landry, J., Martinez, C., and Rochefort, L. 2011. The use of fungicide Nova to mitigate infection of sphagnum by parasitic fungi in the greenhouse. Botany 89:655-661.

Liu, S. M., Gao, X. H., Zhang, Y. H., Li, M., and Mei, X. H. 2014. Detection of the resistance of Botrytis cinema on tomato in Henan Province to three fungicides. Plant Prot. 40:144-147.

Lu, X. M., He, S., Ma, H. J., Li, J. H., and Zhu, F. X. 2018a. Hormetic effects of flusilazole preconditioning on mycelial growth and virulence of Sclerotinia sclerotiorum. Plant Dis. 102:1165-1170.

Lu, X. M., Zhang, R., Cong, M. L., Li, J. H., and Zhu, F. X. 2018b. Stimulatory effects of flusilazole on virulence of Sclerotinia sclerotiorum. Plant Dis. 102:197-201.

Lu, X. M., Zhu, Z. Q., Di, Y. L., and Zhu, F. X. 2015. Baseline sensitivity and toxic action of flusilazole to Sclerotinia sclerotiorum. Crop Prot. 78:92-98.
Mbengue, M., Navaud, O., Peyraud, R., Barascud, M., Badet, T., Vincent, R., Barbacci, A., and Raffaele, S. 2016. Emerging trends in molecular interactions between plants and the broad host range fungal pathogens Botrytis cinerea and Sclerotinia sclerotiorum. Front. Plant Sci. 7:422.

Moorman, G. W., and Kim, S. H. 2004. Species of Pythium from greenhouses in Pennsylvania exhibit resistance to propamocarb and mefenoxam. Plant Dis. 88: 630-632.

Nakajima, M., and Akutsu, K. 2014. Virulence factors of Botrytis cinerea. J. Gen. Plant Pathol. 80:15-23.

Rupp, S., Weber, R. W. S., Rieger, D., Detzel, P., and Hahn, M. 2016. Spread of Botrytis cinerea strains with multiple fungicide resistance in German horticulture. Front. Microbiol. 7:2075.

Saito, S., Michailides, T. J., and Xiao, C. L. 2016. Fungicide resistance profiling in Botrytis cinerea populations from blueberry in California and Washington and their impact on control of gray mold. Plant Dis. 100:2087-2093.

Van Kan, J. A., Stassen, J. H., Mosbach, A., Van Der Lee, T. A., Faino, L., Farmer A. D., Papasotiriou, D. G., Zhou, S., Seidl, M. F., Cottam, E., Edel, D., Hahn, M., Schwartz, D. C., Dietrich, R. A., Widdison, S., and Scalliet, G. 2017. A gapless genome sequence of the fungus Botrytis cinerea. Mol. Plant Pathol. 18:75-89.

Williams, B., Kabbage, M., Kim, H. J., Britt, R., and Dickman, M. B. 2011 Tipping the balance: Sclerotinia sclerotiorum secreted oxalic acid suppresses host defenses by manipulating the host redox environment. PLoS Pathog 7: e1002107.

Williamson, B., Tudzynski, B., Tudzynski, P., and van Kan, J. A. 2007. Botrytis cinerea: The cause of grey mould disease. Mol. Plant Pathol. 8:561-580.

Wojtaszek, P. 1997. Oxidative burst: An early plant response to pathogen infection. Biochem. J. 322:681-692.

Zhang, C. Y., Zhang, Z. X., and Cui, G. R. 2006. Detection and management of the resistance of Botrytis cinerea to fungicides in Anhui Province. Plant Prot. 32: 32-34.

Zhang, S., Panaccione, S. G., and Gallegly, M. E. 1997. Metalaxyl stimulation of growth of isolates of Phytophthora infestans. Mycologia 89:289-292.

Zhou, F., Liang, H. J., Di, Y. L., You, H., and Zhu, F. X. 2014. Stimulatory effects of sublethal doses of dimethachlon on Sclerotinia sclerotiorum. Plant Dis. 98 $1364-1370$

Zhou, M. G., and Ye, Z. Y. 1987. Resistance of plant pathogens to benzimidazole fungicides. Plant Prot. 18:31-33. 